\title{
Rhabdomyolysis Complicating Typhoid Fever in a Child and Review of the Literature
}

\author{
Authors \\ Peter James Snelling1,2 BSc MBBS MPHTM FRACP peter.j.snelling@gmail.com \\ Paul Moriarty ${ }^{3} \quad$ MB BAO BCh, MD \\ Vikram L Vaska ${ }^{4}$ FRACP FRCPA \\ David Levitt ${ }^{1,2}$, FRACP \\ Clare Nourse ${ }^{2,4}$ BA MB BCH BAO DCH MRCPI FRACP MD

\begin{abstract}
1Department of General Paediatrics, Lady Cilento Children's Hospital, Brisbane, ${ }^{2}$ Faculty of Paediatrics, University of Queensland

${ }^{3}$ Royal Belfast Hospital for Sick Children, Belfast

${ }^{4}$ Infection Management and Prevention Service, Lady Cilento Children's Hospital,

Brisbane
\end{abstract}

\section{Corresponding Author}

Peter J Snelling

Lady Cilento Children's Hospital

Level 2 Directorate

501 Stanley Street

South Brisbane

Ph:07 30688111

F: 0730684379

peter.j.snelling@gmail.com

\section{Key Words}

Typhoid fever

Salmonella typhi

Rhabdomyolysis

Septicemia

\section{Abbreviated Title}

Rhabdomyolysis Complicating Typhoid Fever in a Child

\section{Running Head Title}

Rhabdomyolysis Complicating Typhoid Fever

Conflicts of Interest, Funding and Acknowledgments

None to declare 


\begin{abstract}
Typhoid fever is an important cause of morbidity and mortality in the developing world, particularly in children, but is infrequently observed in the developed world and can occur in patients without a significant travel history. Rhabdomyolysis as a complication has rarely been reported, and never in a child. A child with Salmonella enterica serovar Typhi septicemia, complicated by rhabdomyolysis, encephalopathy and pancreatitis is described and all 15 reported cases to date are summarized.
\end{abstract}




\section{Introduction}

2

3 Typhoid fever is an important cause of morbidity and mortality in the developing

4 world, particularly in children, but is infrequently observed in the developed world

5 and can occur in patients without a significant travel history. Multiple organ systems

6 are commonly affected. Rhabdomyolysis as a complication has rarely been

7 reported, and never in a child. This report describes a child with Salmonella enterica

8 serovar Typhi septicemia, complicated by rhabdomyolysis, encephalopathy and 9 pancreatitis.

10

11

\section{Case Report}

13

14 A previously healthy 11-year old girl with no comorbidities presented with a 24-hour 15 history of worsening limb pain, weakness and confusion. This was preceded by a 516 day history of fever, diarrhoea and vomiting but no abdominal pain. At initial assessment, she was febrile (101.5 $\left.{ }^{\circ} \mathrm{F}\right)$ and tachycardic (HR 150), but normotensive (BP 90/65). She was encephalopathic and globally weak with normal deep tendon reflexes. Investigations revealed a normal haemoglobin and white cell count, but raised C-reactive protein $(247 \mathrm{mg} / \mathrm{l})$, urea $(10 \mathrm{mmol} / \mathrm{l})$, creatinine $(150 \mathrm{mmol} / \mathrm{l})$, hepatic enzymes (ALT $108 \mathrm{U} / \mathrm{l}$, AST $481 \mathrm{U} / \mathrm{l})$, lactate dehydrogenase (2399 iu/l), creatinine kinase $(11,899 \mathrm{IU} / \mathrm{L})$ and myoglobinuria. She subsequently developed severe epigastric pain with a transiently elevated lipase $(10,769 \mathrm{U} / \mathrm{l})$ and pancytopaenia (nadir values: haemoglobin $95 \mathrm{~g} / \mathrm{L}$, white cell count $2.4 \mathrm{x} 10^{9} / \mathrm{L}$ and 
platelets $72 \times 10^{9} / \mathrm{L}($ Table 1$\left.)\right)$. There was no evidence of bowel perforation on CT scan of the abdomen.

A diagnosis of rhabdomyolysis associated with acute kidney injury was made. She was admitted to intensive care for hydration with urinary alkalinization, and empiric antibiotic treatment with ceftriaxone, vancomycin and acyclovir.

Numerous investigations were conducted to determine a cause for the sepsis and rhabdomyolysis. Brain MRI demonstrated diffuse restricted diffusion extending to the deep white matter but CSF analysis was normal. Metabolic, autoimmune and toxicology testing were normal. Salmonella enterica serovar Typhi (S. Typhi) was isolated on blood cultures, with initial growth at 15 hours. The patient improved with supportive therapy and IV cefotaxime for 8 days. It was deemed that 7 days of appropriate IV antibiotics would likely be sufficient therapy, but the treating team were cautious because of the severity of the illness and continued antibiotics with IV azithromycin for 7 days and oral azithromycin for a further 7 days. Although the organism was fully sensitive (amoxicillin, cefotaxime, ciprofloxacin), therapy was changed to azithromycin given its excellent intra-cellular penetration and recognized efficacy against $S$. Typhi. ${ }^{1,2}$ She was discharged on day 17.

The patient had no history of recent travel to a typhoid endemic area. She was of Pacific Islander origin but had lived all of her life in New Zealand and Australia. No index case was identified. She made a complete recovery. 


\section{Discussion}

57 Rhabdomyolysis is the destruction of muscle fibres with release of cellular elements 58 into the systemic circulation. ${ }^{5}$ A number of mechanisms have been proposed for 59 rhabdomyolysis in typhoid fever, including sepsis-induced tissue hypoxia, direct 60 bacterial invasion of myocytes, inhibition of muscle glycolytic enzymes and 61 endotoxin-mediated damage.$^{5-7}$ Myalgia is a common presenting complaint and may

65 Rhabdomyolysis has rarely been described in association with typhoid fever, and 66 never in a child. In one literature review in 1996, Salmonella species was found to be the fourth most commonly cited cause of bacteria-induced rhabdomyolysis, with the majority due to non-typhoidal strains. ${ }^{9}$ However, the literature to date includes only 14 cases of $S$. Typhi infection associated with rhabdomyolysis (Table 2)..$^{10-23}$ The mean age of cases is 28 years and there is a male preponderance. All cases had acute kidney injury and recovered normal renal function. The combination of encephalopathy, pancreatitis and rhabdomyolysis has only been reported twice previously and has not been associated with a particularly poor outcome.11,21 Encephalopathy was the most common neurological complication but diffuse axonal 
75 polyneuropathy, cutaneous hyperesthesia and diplopia were also reported. ${ }^{11,17}$

76 Pulmonary complications included bronchopneumonia and pleural effusion. ${ }^{11,17}$

77 Myocarditis was only reported in one case. ${ }^{13}$ Reported hepatobillary complications 78 include hepatitis, hepatosplenomegaly, ascites and conjugated 79 hyperbilirubinemia. ${ }^{13,16,17,18-22}$ However, it can be difficult to distinguish true hepatitis 80 from leakage of muscle cell transaminases.

82 Management of typhoid fever with rhabdomyolysis includes the administration of 83 antibiotic therapy as well as supportive care with hydration and urinary 84 alkalinization. ${ }^{5}$ Although complications can be severe, treatment is associated with 85 an excellent prognosis.

88 Conflicts of interest

89

90 None to declare

\section{References}

94

95 1. Wildfeuer A, Laufen $\mathrm{H}$, Zimmermann $\mathrm{T}$. Uptake of azithromycin by various cells 96 and its intracellular activity under in vivo conditions. Antimicrob Agents Chemother. $97 \quad 1996 ; 40: 75-9$. 
2. Effa EE, Bukirwa H. Azithromycin for treating uncomplicated typhoid and paratyphoid fever (enteric fever). Cochrane Database Syst Rev. 2008;4:CD006083.

3. Commons RJ, McBryde E, Valcanis M, Powling J, Street A, Hogg G. Twenty-six years of enteric fever in Australia: an epidemiological analysis of antibiotic resistance. MJA. 2012; March 196(5):332-336.

4. Leder K, et al. Travel-associated illness trends and clusters, 2000-2010. Emerg Infect Dis. 2013; July 19(7):1049-57

5. Bosch X, Poch E, Grau JM. Rhabdomyolysis and Acute Kidney Injury. N Engl J Med. 2009;361:62-72.

6. Brncic N, Viskovic I, Sasso A, Kraus I, Zamolo G. Salmonella infection-associated acute rhabdomyolysis. Some pathogenic considerations. Arch Med Res. 2002 MayJun;33(3):313-5.

7. Friman G, Ilback NG, Beisel WR. Effects of streptococcus pneumoniae, salmonella typhimurium and francisella tularensis infections on oxidative, glycolytic and lysosomal enzyme activity in red and white skeletal muscle in the rat. Scand $J$ Infect Dis. 1984;16(1):111-9.

8. Bhutta ZA. Current Concepts in the Diagnosis and Treatment of Typhoid Fever. BMJ. 2006; 333:78-82 
9. Singh U, Scheid WM. Infectious etiologies of rhabdomyolysis : three case reports and review. Clin Infect Dis. 1996 April 22: 642-649

10. Non LR, Patel R, Esmaeeli A, Despotovic V. Case Report: typhoid fever complicated by hemophagocytic lymphohistiocytosis and rhabdomyolysis. Am J Trop Med Hyg. 2015; 93(5):1068-1069.

13. Al-aqeedi RF, Kamha A, Al-aani FK, Al-ani AA. Salmonella myocarditis in a young adult patient presenting with acute pulmonary edema, rhabdomyolysis, and multi-organ failure. J Cardiol. 2009 Dec;54(3):475-9.

14. Khan FY, Al-Ani A, Ali HA. Typhoid rhabdomyolysis with acute renal failure and acute pancreatitis: A case report and review of the literature. Int $J$ Infect Dis. 2009 Sep;13(5):e282-5.

15. Fisk DT, Bradley SF. Rhabdomyolysis induced by salmonella enterica serovar typhi bacteraemia. Clin Microbiol Infect. 2004 Jul;10(7):595-7. 
16. Simcock D. Gastroenteritis, fever and myoglobinuric renal failure. J R Soc Med. 2004 Apr;97(4):185-6.

17. Dakdouki GK, Bizri AR. Rhabdomyolysis and salmonella typhi infection: Case report and review of the literature. J Med Liban. 2003 Jul-Sep;51(3):143-7.

18. Loutfy MR, Feld JJ, Conly JM. Multiorgan failure and rhabdomyolysis in a recent émigré: Your diagnosis? Can J Infect Dis. 2000; 11:134-154.

19. Hazouard E, Ferrandiere M, Cattier B, Dequin PF, Legras A, Ginies G. Septic shock with coma revealing typhoid fever. Presse Med. 1998 Sep 5;27(25):1275-6

20. Mody GM, Gathiram V, Abdulla EA. Severe reversible myopathy due to typhoid. J Trop Med Hyg. 1989 Apr;92(2):102-3

21. Ginsburg C, Raffenne L. Typhoid fevers complicated by acute renal failure, by rhabdomyolysis and by acute pancreatitis. Rev Med Interne. 1989 MayJun;10(3):279-80

22. Barnes P, Goldstein DA, Overturf GD. Rhabdomyolysis and pancytopenia in a young man. West J Med. 1986 May;144(5):586-90.

23. Rheingold OJ, Greenwald RA, Hayes PJ, Tedesco FJ. Myoglobinuria and renal failure associated with typhoid fever. JAMA. 1977 Jul 25;238(4):341. 


\begin{tabular}{lllllllllll}
\hline Day of admission & & 1 & 2 & 4 & 7 & 8 & 9 & 11 & 14 & 17 \\
& & & & & & & & & & \\
& & & & & & & & & & \\
& & & & & & & & & & \\
\hline White cell count x 109/L & $(4.5-13.5)$ & 5.9 & 2.3 & 2.4 & 5.8 & 7.1 & 8.8 & 7 & 8.1 & \\
Hemoglobin (g/L) & $(115-155)$ & 127 & 109 & 95 & 104 & 101 & 95 & 91 & 100 & \\
Platlets x109/L & $(150-400)$ & 101 & 86 & 72 & 126 & 161 & 225 & 368 & 416 & \\
Urea (mmol/L) & $(1.0-6.0)$ & 10.8 & 12 & 14.2 & 8.5 & 7.3 & 6.5 & 4.5 & 7.9 & 9 \\
Creatinine (umol/L) & $(20-70)$ & 150 & 207 & 212 & 74 & 62 & 54 & 64 & 77 & 90 \\
Serum albumin (g/L) & $(33-47)$ & 34 & 25 & 21 & 23 & 25 & 27 & 31 & 41 & 42 \\
AST (U/L) & $(10-45)$ & 481 & 451 & 399 & 321 & 262 & 199 & 121 & 74 & 48 \\
ALT (U/L) & $(5-45)$ & 108 & 99 & 105 & 97 & 86 & 100 & 91 & 84 & 71 \\
Creatinine Kinase (U/L) & $(<50)$ & 11899 & 11318 & 4108 & 1538 & 1342 & 1231 & 897 & 299 & 91 \\
Lipase (U/L) & $(<160)$ & & 416 & 1687 & 1605 & 9375 & 10769 & 3136 & 3280 & 2113 \\
CRP (mg/L) & $(<2.0)$ & 247 & 238 & 120 & & 17 & & & 6.5 & \\
\hline
\end{tabular}

Table 1. Laboratory results. 


\begin{tabular}{|c|c|c|c|c|c|c|c|c|c|c|c|}
\hline $\begin{array}{l}\text { Patient } \\
\text { age in } \\
\text { years, } \\
\text { Sex }\end{array}$ & Year & $\begin{array}{l}\text { Origin of } \\
\text { report } \\
\text { (Country } \\
\text { S.Typhi } \\
\text { acquired) }\end{array}$ & $\begin{array}{l}\text { Symptoms } \\
\text { prior to } \\
\text { presentation } \\
\text { (days) }\end{array}$ & Pancreatitis & $\begin{array}{l}\text { Neur } \\
\text { ologi } \\
\text { cal }\end{array}$ & $\begin{array}{l}\text { Cardio } \\
\text { vascul } \\
\text { ar }\end{array}$ & Hepatobillary & Pulmonary & $\begin{array}{l}\text { Recovery of } \\
\text { Renal } \\
\text { function }\end{array}$ & $\begin{array}{l}\text { Renal } \\
\text { Repla } \\
\text { cemen } \\
\mathbf{t} \\
\text { Thera } \\
\text { py }\end{array}$ & Reference \\
\hline $11, F$ & 2016 & Australia & 5 & $\mathrm{Y}$ & $\mathrm{Y}$ & $\mathrm{N}$ & $\mathrm{N}$ & $\mathrm{N}$ & $\mathrm{Y}$ & $\mathrm{N}$ & $\begin{array}{l}\text { Reported } \\
\text { case }\end{array}$ \\
\hline $21, F$ & 2015 & USA (India) & 2 & NR & $\mathrm{N}$ & $\mathrm{N}$ & NR & $\mathrm{N}$ & $\mathrm{Y}$ & $\mathrm{N}$ & Non ${ }^{10}$ \\
\hline 42, M & 2011 & $\begin{array}{l}\text { UAE } \\
\text { (India) }\end{array}$ & 'Few days' & $\mathrm{Y}$ & $Y$ & $\mathrm{~N}$ & $\mathrm{~N}$ & $\mathrm{Y}$ & $Y$ & $\mathrm{Y}$ & Ali ${ }^{11}$ \\
\hline 64, M & 2010 & India & 7 & $\mathrm{NR}$ & $\mathrm{N}$ & NR & $\mathrm{N}$ & $\mathrm{N}$ & $Y$ & $\mathrm{Y}$ & Jhawar $^{12}$ \\
\hline $34, \mathrm{M}$ & 2009 & Qatar & 3 & NR & $Y$ & $Y$ & $Y$ & $\mathrm{~N}$ & $\mathrm{Y}$ & $\mathrm{N}$ & Al-aqueedi ${ }^{13}$ \\
\hline 23, M & 2009 & $\begin{array}{l}\text { Qatar } \\
\text { (Vietnam) }\end{array}$ & 15 & $\mathrm{Y}$ & $\mathrm{N}$ & $\mathrm{NR}$ & $\mathrm{N}$ & NR & $Y$ & $\mathrm{~N}$ & Khan $^{14}$ \\
\hline 25, M & 2004 & $\begin{array}{l}\text { USA } \\
\text { (Pakistan) }\end{array}$ & 5 & $\mathrm{NR}$ & $\mathrm{N}$ & $\mathrm{N}$ & $\mathrm{N}$ & $\mathrm{N}$ & $\mathrm{Y}$ & $\mathrm{N}$ & Fisk $^{15}$ \\
\hline $29, F$ & 2004 & $\begin{array}{l}\text { UK } \\
\text { (India) }\end{array}$ & 14 & NR & $\mathrm{N}$ & $\mathrm{N}$ & $\mathrm{Y}$ & $\mathrm{N}$ & $Y$ & $\mathrm{~N}$ & Simcock $^{16}$ \\
\hline $16, F$ & 2003 & Lebanon & 12 & NR & $Y$ & $N$ & $\mathrm{Y}$ & Y & $Y$ & Y & Dakdouki ${ }^{17}$ \\
\hline 21, M & 2000 & $\begin{array}{l}\text { Canada } \\
\text { (India) }\end{array}$ & 9 & $\mathrm{~N}$ & $Y$ & $\mathrm{~N}$ & Y & $\mathrm{N}$ & $Y$ & Y & Loutfy ${ }^{18}$ \\
\hline $20, F$ & 1998 & France & NR & NR & Y & $N$ & $\mathrm{Y}$ & $N$ & Y & $N$ & Hazouard $^{19}$ \\
\hline $18, M$ & 1989 & S. Africa & 10 & $\mathrm{NR}$ & $\mathrm{N}$ & $\mathrm{N}$ & $\mathrm{N}$ & $\mathrm{N}$ & $\mathrm{Y}$ & $\mathrm{N}$ & Mody 20 \\
\hline $17, \mathrm{~F}$ & 1989 & Senegal & 5 & $\mathrm{Y}$ & $Y$ & $\mathrm{~N}$ & $\mathrm{~N}$ & $\mathrm{~N}$ & $Y$ & $Y$ & Ginsburg $^{21}$ \\
\hline 26, M & 1986 & USA & 8 & $\mathrm{NR}$ & Y & $\mathrm{N}$ & $\mathrm{Y}$ & Y & Y & $\mathrm{N}$ & Barnes $^{22}$ \\
\hline 32, M & 1977 & USA & 6 & NR & $\mathrm{N}$ & $\mathrm{N}$ & $\mathrm{N}$ & $\mathrm{N}$ & $Y$ & $\mathrm{~N}$ & Rheingold ${ }^{23}$ \\
\hline
\end{tabular}

Table 2. Details of previously reported cases of typhoid fever complicated by rhabdomyolysis. 